\title{
VERIFICATION OF THE SIMULATION MODEL BASED ON THE EXAMPLE OF COMBINED SEWAGE SYSTEM IN GLOGÓW
}

\author{
Ireneusz NOWOGOŃSKI ${ }^{1}$ \\ University of Zielona Gora, Poland
}

\begin{abstract}
The verification of simulation model of combined sewage system was presented in article. The model of sewage system functioning in Głogów was developed using SWMM 5.1 (Storm Water Management Model) software. It was calibrated based on the results of field studies from the years 2011-13, while the properness of its activity was verified for the results of measurements carried out in 2014. The verification of the model showed acceptable discrepancies between the measured and simulated values of flow rates. Factors which caused differences were indicated and, on the basis of this, conclusions pertaining to further studies were formulated.
\end{abstract}

Keywords: combined sewage system, rainfall-runoff phenomena, simulation model

\section{INTRODUCTION}

The issue of using computer models to enable the simulation of the operating conditions of storm drainage or a combined sewage system during the course of a rainfall event is one of the more important issues which may be encountered by users of sewage systems in the near future. All works, for example, connected with the modernization of the system and its parts ought to be preceded by

\footnotetext{
${ }^{1}$ Corresponding author: University of Zielona Góra, Institute of Environmental Engineering, Szafrana 15, 65-246 Zielona Góra, Poland, e-mail: i.nowogonski@iis.uz.zgora.pl, tel. +48683282570
} 
studies and an assessment of its day-to-day functioning. The introduction of properly calibrated theoretical models has become a necessity, above all from the technical point of view (analysis of expansion in the system, the possibility of connecting additional catchments or sewage sources, carrying out trenchless renovation). The work makes use of experience gained at the phase of implementing a model of the combined sewage system in Głogów. The realized studies resulted from the need to verify the number of storm water outflow activations over the course of a year.

\section{MATERIALS AND METHODOLOGY}

Głogów - a city in eastern Poland in Lower Silesia Province - is located on the Oder River, with the number of inhabitants exceeding 68 thousand. The sewage system in Głogów is mainly realized as a combined system. Only the newest estates are equipped with a separate sewerage system. The progressive sealing of the catchment and uncontrolled development of the sewage network in connection with the more and more frequently occurring weather anomalies has caused streets and squares to be regularly flooded with sewage, as well as the flooding of residential buildings.

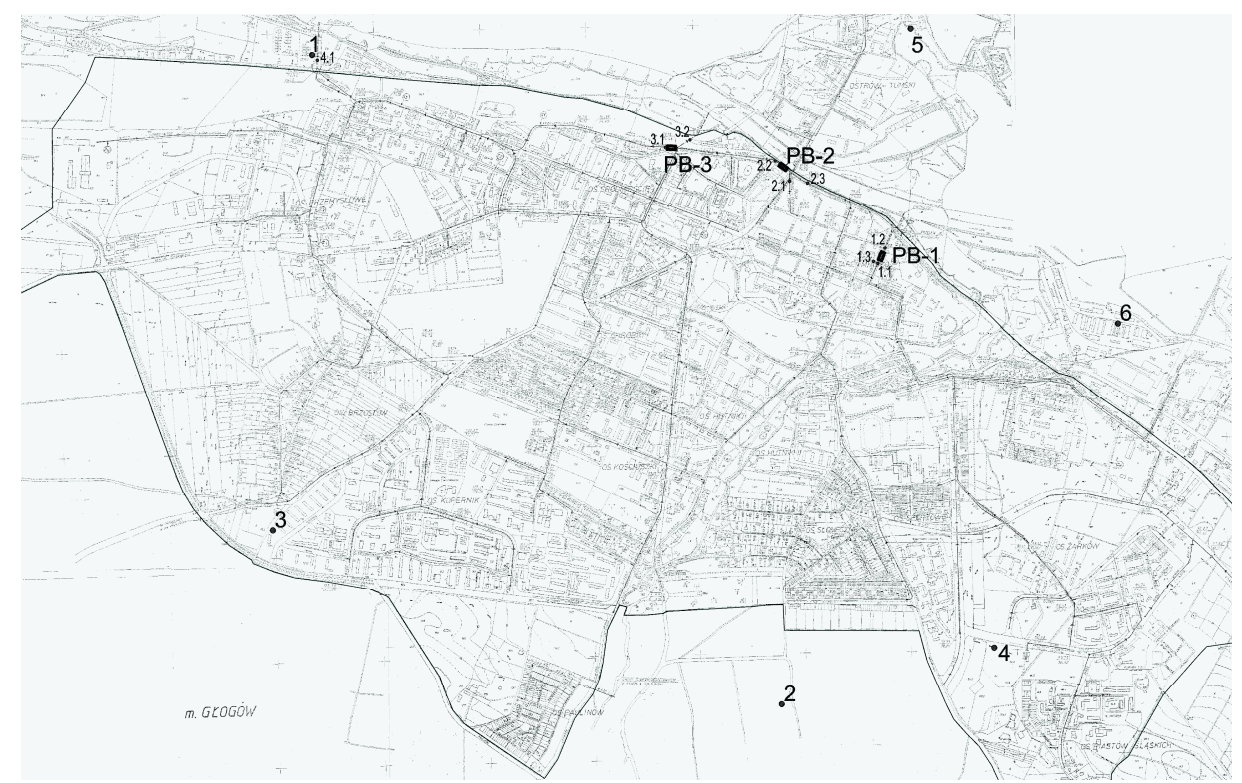

Fig. 1. Location of rain gauges and measurement stations in the area of the city in the period 2011-2014: PB-1-4 - overflow structures; 1.1-4.1 - measurement stations; $1-6$ - rain gauges [3] 
Works aimed at solving this problem have been carried out for many years now. One of the main tasks was to develop a simulation model of the combined sewage system enabling the analysis of potential solutions and their current, as well as future influence on the sewage system.

The other purpose for developing the model was the implementation of a solution enabling the amount of occurrences of storm water outflows to the Oder River to be verified. Binding regulations allow for the storm water outflow to be activated 10 times within the course of a year. Information on this topic can be based on a constant monitoring system of the depth of runoff in the storm water drain or in the overflow crests. It is also possible to apply a calibrated simulation model using rain gauge data. The model also serves as a tool enabling the verification of the amount of times storm water was discharged into the Oder River after disassembling the measurement system in channels.

Table 1. Parameters used for the hydraulic calibration of the model [5]

\begin{tabular}{|l|c|c|}
\hline Parameters & $\begin{array}{c}\text { Rank of variation } \\
\text { allowed }\end{array}$ & $\begin{array}{c}\text { Initial value } \\
\text { taken }\end{array}$ \\
\hline Average impermeable area & $\pm 10 \%$ & $17.7 \%$ \\
\hline Average width & $\pm 30 \%$ & $44.9 \mathrm{~m}$ \\
\hline Average slope & $\pm 30 \%$ & $13.1 \%$ \\
\hline Surface storage & $0.3-2.5 \mathrm{~mm}$ & $1.0 \mathrm{~mm}$ \\
\hline Impermeable area & $2.5-5.1 \mathrm{~mm}$ & $2.0 \mathrm{~mm}$ \\
\hline Permeable area & & $25 \mathrm{~mm}$ \\
\hline Infiltration equation of Horton & $0.0-10 \mathrm{~mm}$ & $1.0 \mathrm{~mm}$ \\
\hline Maximum infiltration, $\mathrm{f}_{0}\left(\mathrm{~L}^{-} \mathrm{T}^{-1}\right)$ & $0.00056-0.00139 \mathrm{~s}^{-1}$ & $0.00115 \mathrm{~s}^{-1}$ \\
\hline Minimum infiltration, $\mathrm{f}_{\mathrm{c}}\left(\mathrm{L} \cdot \mathrm{T}^{-1}\right)$ & & \\
\hline Decay coefficient, $\mathrm{k}\left(\mathrm{T}^{-1}\right)$ & $0.02-0.45$ & 0.10 \\
\hline Manning's roughness coefficient & $0.010-0.015$ & 0.012 \\
\hline Permeable area & $0.011-0.013$ & 0.013 \\
\hline Impermeable area & & \\
\hline Pipes & & \\
\hline
\end{tabular}

On the basis of the gathered data, a model was developed based on [4]:

- nodes - 499 junctions and 4 outlets;

- conduits - 504 channel segments;

- rainfall data - 6;

- rainfall catchments - 370 catchments;

- number of overflow structures - 4 . 
Table 2. Rainfall characteristics in the summer months of 2012-2014

\begin{tabular}{|c|c|c|c|}
\hline Year/Month & 2012 & 2013 & 2014 \\
\hline \multicolumn{4}{|c|}{ Rainfall total in month [mm] } \\
\hline May & $27.7-42.5$ & $62.0-80.8$ & 79.5-98.9 \\
\hline June & $105.1-132.9$ & $90.5-121.1$ & $31.4-54.0$ \\
\hline July & $81.0-119.2$ & $78.1-98.5$ & $41.8-70.1$ \\
\hline August & $46.0-55.2$ & $31.2-42.3$ & $55.4-65.1$ \\
\hline \multicolumn{4}{|c|}{ Maximum daily total in month [mm] } \\
\hline May & $9.1-13.6$ & $13.3-20.8$ & 20.9-33.2 \\
\hline June & $25.5-37.2$ & $29.0-38.1$ & $9.7-25.1$ \\
\hline July & $21.3-32.9$ & $52.2-72.5$ & 18.3-32.9 \\
\hline August & $8.7-12.9$ & $11.1-14.1$ & $19.4-30.8$ \\
\hline \multicolumn{4}{|c|}{ Maximum hourly total in month [mm] } \\
\hline May & $3.3-9.1$ & $3.6-6.7$ & $9.5-22.9$ \\
\hline June & 10.4-13.2 & $6.3-8.7$ & $4.6-14.8$ \\
\hline July & $12.5-27.3$ & $26.0-36.3$ & $6.3-23.6$ \\
\hline August & $5.1-11.3$ & $7.8-10.1$ & $17.3-30.3$ \\
\hline
\end{tabular}

The model was calibrated based on the results of field studies carried out from 1 September 2011 to the end of October 2013, using standard calibration parameters (Table 1) [2,5]. Rainfall characteristics in months from May to August are presented in table 2.

The measurements covered the runoff depth within the overflow crests in three storm overflow structures, as well as the depth and intensity of flows in the inlet and outlet overflow channels. Six rain measurement stations were located within the area of the city according to the scheme presented in Figure 1.

\section{RESULTS AND DISCUSSION}

For assessing the quality of the simulation models, classical statistical measures are recommended for comparing the results of calculations of runoff with the results of measurements (Table 3 ):

- relative residual error (RRE);

- Pearson's correlation coefficient (R);

- Special RS correlation coefficient. 
Table 3. Classification of the quality of the model based on the values of selected indicators [1]

\begin{tabular}{|c|c|c|}
\hline \multirow{2}{*}{ Category of model } & \multicolumn{2}{|c|}{ Indicators and ranges of data } \\
\cline { 2 - 3 } & R, RS [-] & RRE [\%] \\
\hline Very good & $1.00-0.99$ & $0-3$ \\
\hline Good & $0.99-0.95$ & $3-6$ \\
\hline Average & $0.95-0.90$ & $6-10$ \\
\hline Unsatisfactory & $0.90-0.85$ & $10-25$ \\
\hline
\end{tabular}

Assessment of the usefulness of the model was carried out based on relative residual error RRE estimated as [1]:

$$
R R E=\frac{\sqrt{\sum_{i=1}^{n}\left(Q_{p, i}-Q_{o, i}\right)^{2}}}{\sum_{i=1}^{n} Q_{o, i}}
$$

where:

$\mathrm{Q}_{\mathrm{o}}$ - calculated flow rate;

$\mathrm{Q}_{\mathrm{p}}$ - measured flow rate.

The analysis covered 36 runoff periods connected with 10 rainfall events with an intensity of 7.8 to $130.2 \mathrm{~mm} / \mathrm{h}$. The characteristics of selected rainfalls were presented in Table 2.

Table 4. Characteristics of phenomena used for the verification of the model

\begin{tabular}{|c|c|c|}
\hline $\begin{array}{c}\text { Date of } \\
\text { occurrence }\end{array}$ & $\begin{array}{c}\text { Daily rainfall total } \\
{[\mathrm{mm}]}\end{array}$ & $\begin{array}{c}\text { Maximum 5-minute } \\
\text { total [mm] }\end{array}$ \\
\hline 24.05 .2014 & $12.98-26.50$ & $3.30-9.51$ \\
\hline 27.05 .2014 & $10.48-17.92$ & $0.80-1.99$ \\
\hline 28.05 .2014 & $11.83-19.33$ & $0.65-1.28$ \\
\hline 24.06 .2014 & $6.28-12.1$ & $1.51-2.89$ \\
\hline 09.07 .2014 & $10.93-32.94$ & $3.52-6.78$ \\
\hline 03.08 .2014 & $19.39-30.78$ & $5.78-10.85$ \\
\hline 05.08 .2014 & $16.34-21.22$ & $0.76-4.02$ \\
\hline 05.08 .2014 & $16.34-21.22$ & $0.76-4.02$ \\
\hline 09.09 .2014 & $3.87-6.60$ & $0.69-1.94$ \\
\hline 11.09 .2014 & $9.69-11.03$ & $0.65-0.96$ \\
\hline 20.09 .2014 & $3.87-13.93$ & $0.86-5.98$ \\
\hline
\end{tabular}


In the case of relative residual error, a very good result was obtained in 2 cases, with a good result also noted in 11; in 11 cases the result was assessed as average, whereas in 12 - unsatisfactory (Table 5).

The vast majority of the analysed rainfall events provided acceptable results classified as average, good or very good in regard to residual error. Exemplary results have been presented in Figures 2 - 5.

Table 5. Relative residual error (RRE)

\begin{tabular}{|c|c|c|c|c|c|c|}
\hline \multirow{3}{*}{$\begin{array}{c}\text { Date of } \\
\text { occurrence }\end{array}$} & P. Skargi street & \multicolumn{3}{|c|}{ Nadbrzeżna street } & \multicolumn{2}{|c|}{ Towarowa street } \\
\hline & \multicolumn{6}{|c|}{ Measurement stations } \\
\hline & 1.3 & 2.1 & 2.2 & 2.3 & 3.1 & 3.2 \\
\hline 24.05 .2014 & 7.8 & - & - & 5.4 & - & - \\
\hline 27.05 .2014 & - & - & - & 19.8 & - & - \\
\hline 28.05 .2014 & 6.8 & 7.1 & - & 1.3 & 1.7 & - \\
\hline 24.06 .2014 & 6.3 & 15.8 & 4.2 & 3.2 & 4.4 & - \\
\hline 09.07.2014 & 9.6 & - & 5.8 & 3.1 & 6.9 & 12.0 \\
\hline 03.08 .2014 & - & - & - & 5.1 & - & - \\
\hline 05.08 .2014 & - & - & 15.0 & 6.1 & - & - \\
\hline 05.08 .2014 & - & - & 7.0 & 5.3 & - & - \\
\hline 09.09 .2014 & - & 19.3 & 9.1 & 9,0 & - & 20.0 \\
\hline 11.09 .2014 & 10.0 & 11.9 & 4.0 & 3.8 & 15.1 & 13.5 \\
\hline 20.09 .2014 & - & 19.5 & - & 4.8 & 20.0 & 13.0 \\
\hline
\end{tabular}

The observable differences between the obtained results of measurements and results obtained as a result of simulations can be partially explained by:

- no rain gauge measurement in the city center (analysis of the scope of the occurrence of rain in the area covered by the analysed sewage system needs optimization);

- partial lack of measurement data due to the accumulation of deposits during the event.

The example shown in figure 2 corresponds to the parameter RRE classified as very good. The intensity of the recorded rainfall was low and precipitation were classified as long-term. 


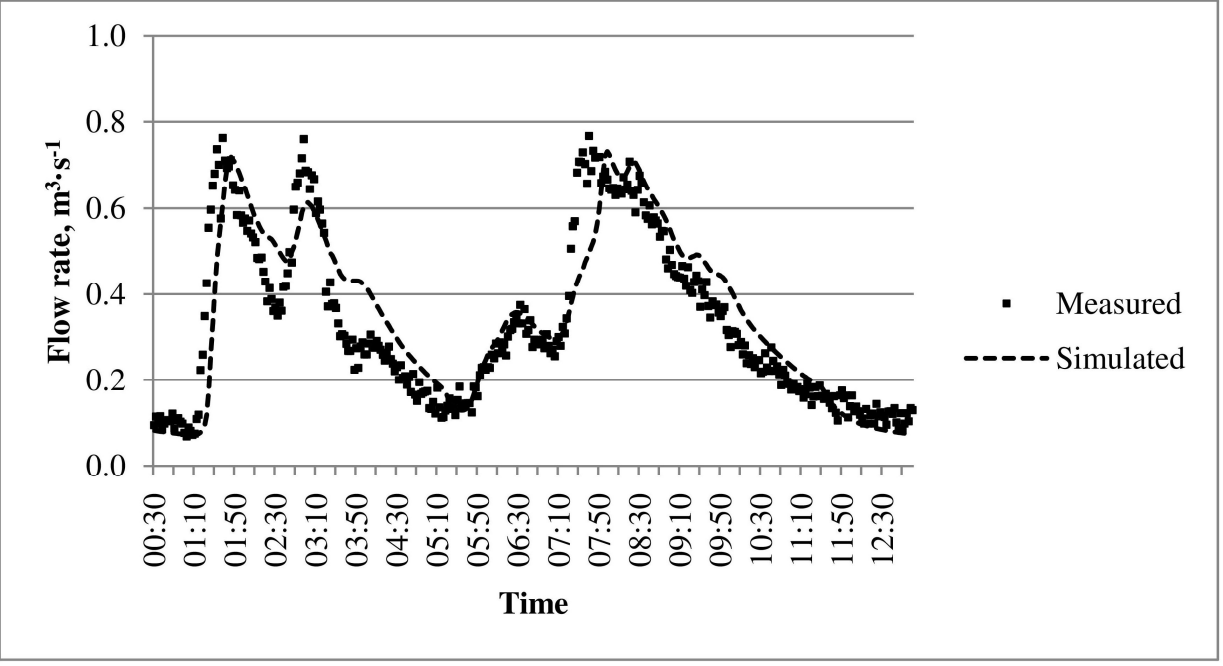

Fig. 2. Flowrate in channel - 28.05.2014 - Measurement Point 2.3.

The example shown in figure 3 corresponds to an RRE parameter between good and medium. The intensity of the recorded rainfall was low and precipitation were classified as long-term.

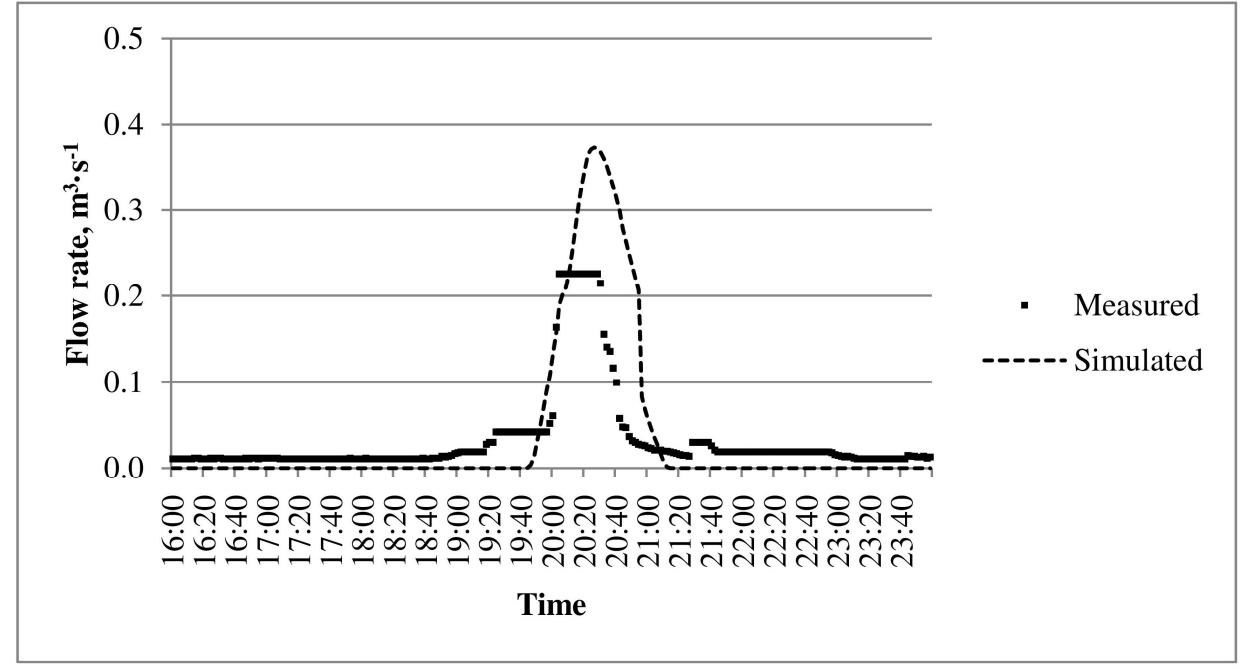

Fig. 3. Flowrate in channel - 11.09.2014 - Measurement Point 1.3.

The example shown in figure 4 corresponds to the parameter RRE classified as good and shown in figure 5 corresponds to the parameter RRE classified as average. Spatial variability of rainfall intensity of recorded precipitation was 
considerable in the initial period, and the precipitation consisted of two phenomena. Spatial variability of intensity causes the weakening of the quality of simulation in the first phase of the phenomenon.

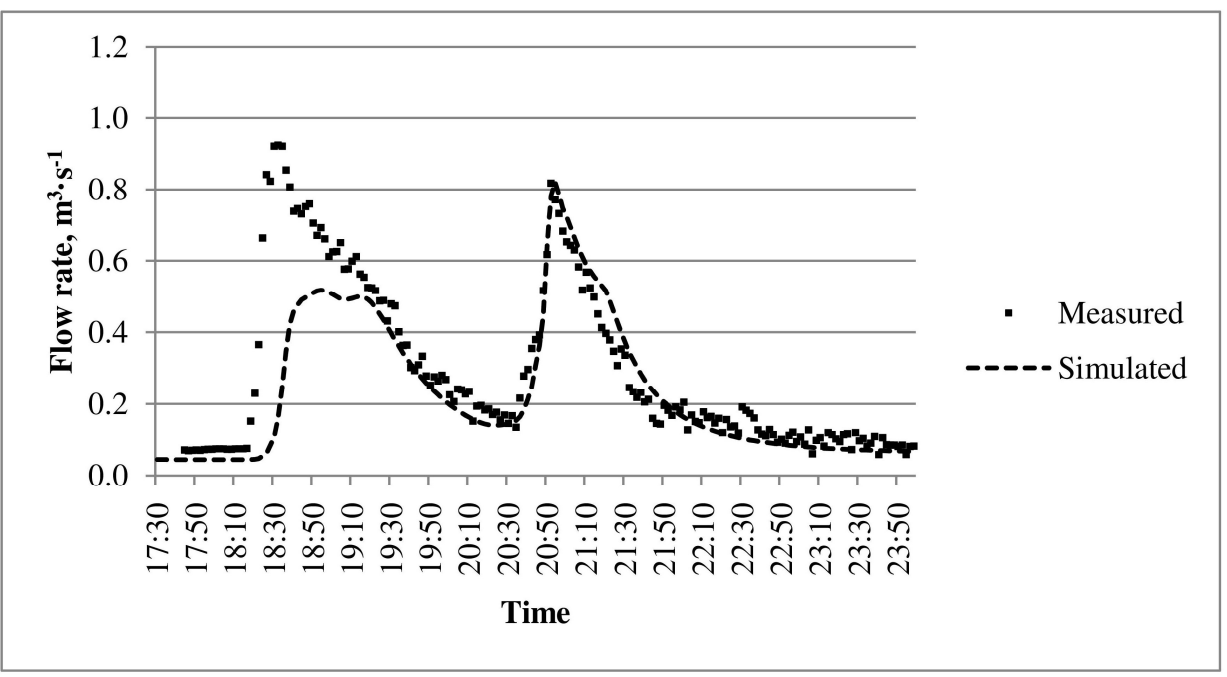

Fig. 4. Flowrate in channel - 20.09.2014 - Measurement Point 2.3.

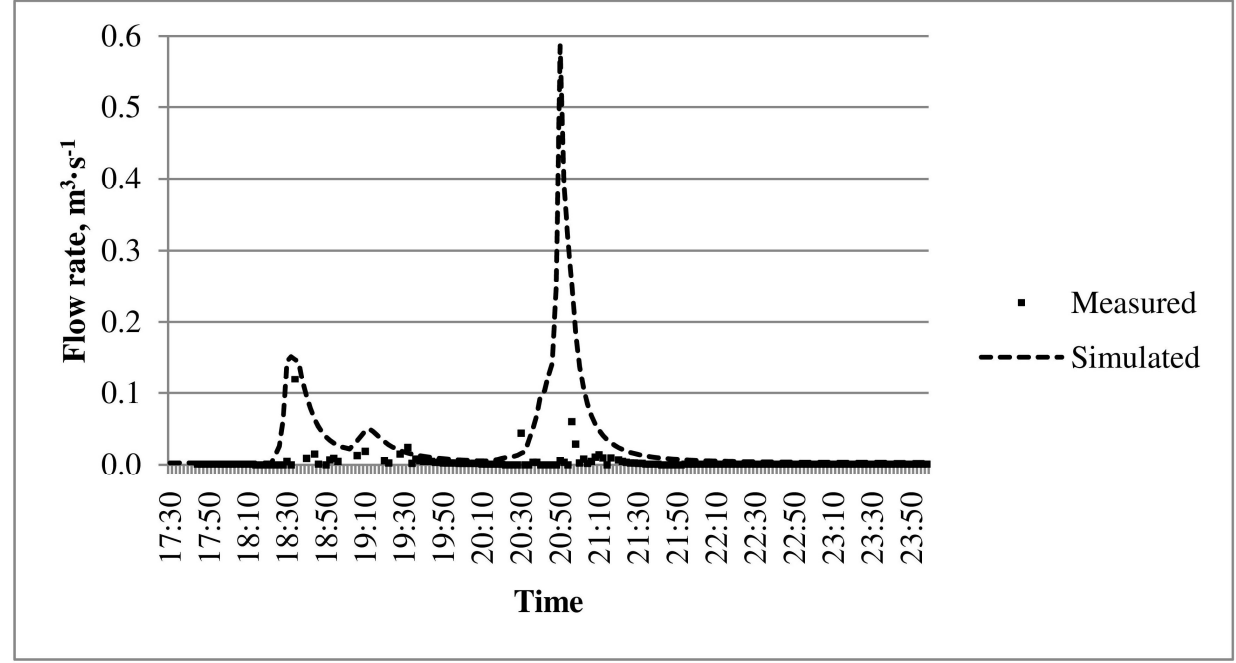

Fig. 5. Flowrate in channel - 20.09.2014 - Measurement Point 2.1. 


\section{CONCLUSION}

The possibility of the proper calibration of the model of the storm drainage and combined sewage system is strictly connected with the reliability of measurement data from the area of the catchment. Conclusions drawn from the realized field studies and implemented simulation models make it possible to state that the existing rain measurement network realized by the Institute of Meteorology and Water Management is too scattered; thus the necessity of building local networks of rain measurement stations enabling the rain coverage of only a part of the analysed catchment to be accounted for. In the current state, the model can be applied to assess the number of storm water overflow structure activations based on currently registered meteorological data. As an effect, the analysis of the obtained results of simulations made it possible to formulate the following conclusions:

- in the case of cities of up to 100 thousand inhabitants, it is not possible to leave out the spatial variability of rainfall intensity;

- the traditional approach, i.e. invariable rainfall model connected with the catchments, may cause significant errors in the proper design of sewage systems;

- using the simulation model as a tool replacing the constant monitoring of runoff in storm water drains requires the maintenance of rain gauge monitoring with a density enabling the analysis of the scope of the occurrence of rain in the area covered by the analysed sewage system;

- the existing network for monitoring meteorological data used by the Institute of Meteorology and Water Management does not constitute a sufficient database for implementing and using local simulation models of storm water drainage networks;

- implementing simulation models ought to be preceded by an economic analysis of developing a simulation model and the costs of maintaining a network of rain gauges as compared to the maintenance of constant monitoring in storm water drains.

\section{REFERENCES}

1. Kotowski A.: The Basics of Safe Dimensioning of Site Drainage (Podstawy bezpiecznego wymiarowania odwodnień terenów) [in Polish], Warszawa Seidel-Przywecki 2015.

2. Nowogoński I., Wira J.: Kalibracja hydrauliczna modelu SWMM przy wykorzystaniu danych z badań na terenie miasta Gtogowa, Instal, 9 (2006), 81-84. 
3. Nowogoński I.: Wstępna ocena monitoringu opadów atmosferycznych $i$ sygnalizacji wystapienia odptywów burzowych na terenie miasta Gtogów, in: Zeszyty Naukowe Uniwersytetu Zielonogórskiego, seria: Inżynieria Środowiska nr 26 / 2012, 32-43.

4. Rossman L. A.: Storm Water Management Model. User's Manual. Version 5, Cincinnati, National Risk Management Research Laboratory Office of Research and Development U. S. Environmental Protection Agency 2010.

5. Temprano J., Arango Ó., Cagiao J., Suárez J., Tejero I., Stormwater quality calibration by SWMM: A case study in Northern Spain, Water SA Vol 32, No 1 (2005), 55-63.

\section{WERYFIKACJA MODELU SYMULACYJNEGO NA PRZYKŁADZIE SIECI KANALIZACJI OGÓLNOSPŁAWNEJ MIASTA GŁOGOWA}

\section{Streszczenie}

Przy użyciu programu SWMM 5.1 (Storm Water Management Model) opracowano model symulacyjny istniejącej sieci kanalizacyjnej w Głogowie. Model został skalibrowany na podstawie wyników badań terenowych z lat 2011-13, a prawidłowość jego działania zweryfikowano przy użyciu wyników pomiarów przeprowadzonych w 2014 roku. Weryfikacja modelu wykazała akceptowalne rozbieżności między zmierzonymi i symulowanymi wartościami natężenia przepływu. Wskazano czynniki, które spowodowały różnice i na tej podstawie sformułowano wnioski dotyczące dalszych badań.

Słowa kluczowe: kanalizacja ogólnospławna, zjawisko opad-odpływ, modele symulacyjne 